\title{
Badania właściwości powłok Zn i Al natryskiwanych łukowo na stal S235JR
}

\section{Investigation of the properties of $\mathrm{Zn}$ and Al coatings deposited by arc spraying onto S235JR steel substrate}

\section{Streszczenie}

W artykule przedstawiono wyniki badań właściwości powłok cynkowych i aluminiowych natryskiwanych łukowo na podłoże ze stali S235JR wg PN-EN 10025. Powłoki natryskiwano agregatem Metallisation S350. W ramach prowadzonych badań scharakteryzowano mikrostrukturę powłok, ich twardość i przyczepność do podłoża.

W sposób pośredni określono poziom naprężeń własnych w powłokach, dokonując precyzyjnego pomiaru ugięcia próbek i wyznaczenia na tej podstawie wartości naprężenia średniego.

Słowa kluczowe: natryskiwanie cieplne, powłoki anodowe

\section{Abstract}

The article presents results of research of the properties of $\mathrm{Zn}$ and Al coatings deposited by arc spraying method onto a substrate of S235JR steel according to PN-EN 10020. In this study the microstructure of the coatings was characterized together with their hardness and adhesion to the substrate.

In an indirect way, the level of coating residual stresses were calculated, through the precise measurement of sample deflection that was used to calculate the stress magnitude.

\section{Wstęp}

Powłoki cynkowe i aluminiowe na podłożu stalowym stanowią anodowy protektor podłoża przed korozją elektrochemiczną. Wytwarzanie powłok metalowych przez natryskiwanie cieplne, nazywane również metalizacją natryskową, znane jest już od ponad wieku, a prekursorem tej metody w Polsce jest Instytut Mechaniki Precyzyjnej w Warszawie. Natryskiwanie termiczne od początku swego istnienia jest nieustannie rozwijane, zarówno pod względem stosowania nowych źródeł ciepła, konstrukcji urządzeń, jak i modyfikacji materiałów powłokowych. Natryskiwanie termiczne cynku i aluminium realizuje się najczęściej metodą łukową, ewentualnie płomieniową odmianą poddźwiękową. Stosowanie wysokoenergetycznych metod natryskiwania, takich jak płomieniowe naddźwiękowe czy plazmowe, do natryskiwania cynku i aluminium nie znajduje szerokiego zastosowania. $Z$ jednej strony wynika to $z$ relatywnie niskich wartości temperatury topnienia cynku i aluminium, a $z$ drugiej od powłok ochronnych anodowych nie jest oczekiwana wysoka

Dr hab. inż. Tomasz Chmielewski, prof. PW; dr hab. inż. Dariusz Golański, prof. PW; mgr inż. Grzegorz Gontarz Politechnika Warszawska; mgr inż. Janusz Bazela - SciTeeX Sp. z o.o. 
przyczepność czy niska porowatość, gdyż ochrona katodowa nie jest od nich zależna. Natryskiwanie powłok anodowych na stal jest alternatywą dla ogniowego i galwanicznego cynkowania stali. Ze względu na różne uwarunkowania techniczno-ekonomiczne, natryskiwanie cynku, czy aluminium w celu ochrony katodowej stosuje się najczęściej do konstrukcji o znacznych rozmiarach przekraczających gabaryty wanien cynkowniczych (np. przęsła mostów), a także w przypadku konstrukcji trwale związanych z miejscem eksploatacji lub gdy za wysokie stężenie krzemu i węgla w stali utrudnia cynkowanie ogniowe. Natryskiwanie termiczne powłok anodowych ma również tę zaletę, że może być stosowane lokalnie, np. w miejscu naprawy spoiny czy innego elementu konstrukcji stalowej.

\section{Ochrona elektrochemiczna metali}

Metody ochrony elektrochemicznej są oparte na zmianie potencjału elektrodowego metalu w celu zahamowania lub ograniczenia jego rozpuszczania w środowisku korozyjnym. W zależności od kierunku przesuwania potencjału elektrodowego chronionego metalu do wartości niższej lub wyższej (do zakresu pasywnego) rozróżniane są metody ochrony katodowej i anodowej. Cynk i aluminium jako materiały mniej szlachetne w stosunku do stali, tj. będące wobec stali anodą, tworzą ochronę katodową. Ochrona katodowa oznacza, że przedmiot poddany ochronie spełnia rolę katody w korozyjnym ogniwie galwanicznym. Potencjał elektrodowy chronionego metalu przesuwa się w kierunku dodatnim, a więc roztwarzanie (utlenianie) tego metalu jest ograniczone. Metal chroniony jest katodą, na której mogą zachodzić tylko reakcje redukcji. Rozróżnia się ochronę katodową galwaniczną i elektrolityczną $[1 \div 3,10]$.

Galwaniczna ochrona katodowa nazywana również protektorową zachodzi bez użycia zewnętrznego źródła prądu. Chroniony przedmiot (stal) jest katodą ogniwa galwanicznego, którego anodę stanowi celowo tracony metal mniej szlachetny (Zn, Al lub ich stopy) zwany protektorem. Protektor, roztwarzając się, zabezpiecza chroniony przedmiot. Protektorem może być powłoka na metalu chronionym (np. cynk na stali) lub odpowiednio rozmieszczone płyty anodowe. Dobór rodzaju materiału powłoki przeciwkorozyjnej jest uzależniony od środowiska, w jakim ma być eksploatowana, a grubość determinuje okres trwałości, jak przedstawiono w tablicy I. Dla środowiska kwaśnego stosuje się powłoki aluminiowe, a dla środowiska o odczynie zasadowym powłoki cynkowe.

Elektrolityczna ochrona katodowa ma miejsce wówczas, gdy chroniony przedmiot jest katodą ogniwa zasilanego prądem stałym z zewnętrznego źródła prądu (zasilacza elektrycznego). Pomocnicza anoda jest najczęściej wykonana z materiału nieulegającego roztwarzaniu (Pt, $\mathrm{Pb}, \mathrm{Ni})$.
Tablica I. Grubość powłok ochronnych z cynku, aluminium i ich stopów, natryskiwanych cieplnie na stal, zależnie od warunków eksploatacji i wymaganej twardości wg PN-H-04684 (M - powłoka uszczelniana jedną warstwą powłoki malarskiej lub pokryta wielowarstwową powłoką malarską)

Table I. The thickness of the protective coatings of $\mathrm{Zn}$ and $\mathrm{Al}$ or their alloys, deposited by thermal spraying onto the steel substrate, depending upon operating conditions and the required hardness according to $\mathrm{PN}-\mathrm{H}-04684$ ( $\mathrm{M}$ - the sprayed coating with additional covering with one or multi-layer of paint coat)

\begin{tabular}{|c|c|c|c|c|c|}
\hline \multirow{3}{*}{ Środowisko } & \multirow{3}{*}{$\begin{array}{l}\text { Materiał } \\
\text { powłoki }\end{array}$} & \multicolumn{4}{|c|}{ Minimalna grubość powłoki, $\mu \mathrm{m}$} \\
\hline & & \multicolumn{4}{|c|}{ Trwałość powłoki, liczba lat } \\
\hline & & $5 \div 10$ & $10 \div 20$ & $20 \div 30$ & $>40$ \\
\hline \multirow{4}{*}{$\begin{array}{c}\text { Atmosfera } \\
\text { przemysłowa }\end{array}$} & $\mathrm{Zn}$ & $150 \mathrm{M}$ & 200M & - & - \\
\hline & $\mathrm{Al}$ & $\begin{array}{c}200 \\
150 M\end{array}$ & $\begin{array}{c}200 \\
150 M\end{array}$ & $\begin{array}{c}300 \\
200 M\end{array}$ & $\begin{array}{c}350 \\
250 M\end{array}$ \\
\hline & $\mathrm{ZnAl15}$ & $\begin{array}{c}150 \\
120 M\end{array}$ & $\begin{array}{c}200 \\
150 M\end{array}$ & $\begin{array}{c}300 \\
200 M\end{array}$ & \\
\hline & AlMg5 & $\begin{array}{c}200 \\
150 M\end{array}$ & $\begin{array}{c}200 \\
150 M\end{array}$ & $\begin{array}{c}300 \\
200 M\end{array}$ & $\begin{array}{c}350 \\
250 \mathrm{M}\end{array}$ \\
\hline \multirow{4}{*}{$\begin{array}{c}\text { Atmosfera } \\
\text { morska }\end{array}$} & $\mathrm{Zn}$ & $\begin{array}{c}200 \\
150 M\end{array}$ & $\begin{array}{c}250 \\
200 M\end{array}$ & $\begin{array}{c}350 \\
250 M\end{array}$ & \\
\hline & $\mathrm{Al}$ & $\begin{array}{c}250 \\
200 M\end{array}$ & $\begin{array}{c}300 \\
250 M\end{array}$ & $\begin{array}{c}350 \\
250 M\end{array}$ & \\
\hline & $\mathrm{ZnAl15}$ & $\begin{array}{c}150 \\
100 \mathrm{M}\end{array}$ & $\begin{array}{c}200 \\
150 M\end{array}$ & $\begin{array}{c}250 \\
200 M\end{array}$ & $\begin{array}{c}350 \\
300 \mathrm{M}\end{array}$ \\
\hline & AlMg5 & $\begin{array}{c}250 \\
200 M\end{array}$ & $\begin{array}{c}300 \\
350 M\end{array}$ & $\begin{array}{c}350 \\
250 M \\
\end{array}$ & \\
\hline \multirow{4}{*}{ Woda słodka } & $\mathrm{Zn}$ & $\begin{array}{c}200 \\
100 M\end{array}$ & $\begin{array}{c}250 \\
150 M\end{array}$ & $\begin{array}{c}300 \\
200 M\end{array}$ & $\begin{array}{c}350 \\
250 \mathrm{M}\end{array}$ \\
\hline & $\mathrm{Al}$ & $\begin{array}{c}200 \\
150 M\end{array}$ & $\begin{array}{c}250 \\
150 M\end{array}$ & $250 M$ & $300 \mathrm{M}$ \\
\hline & $\mathrm{ZnAl15}$ & $\begin{array}{c}150 \\
100 M \\
\end{array}$ & $\begin{array}{c}200 \\
120 M\end{array}$ & $\begin{array}{c}250 \\
150 M\end{array}$ & $\begin{array}{c}300 \\
200 M\end{array}$ \\
\hline & AlMg5 & $\begin{array}{c}200 \\
150 M\end{array}$ & $\begin{array}{c}250 \\
200 M\end{array}$ & $250 \mathrm{M}$ & $300 \mathrm{M}$ \\
\hline \multirow{4}{*}{$\begin{array}{l}\text { Woda } \\
\text { morska }\end{array}$} & $\mathrm{Zn}$ & $\begin{array}{c}150 M \\
250\end{array}$ & $\begin{array}{c}200 M \\
350 \\
\end{array}$ & & \\
\hline & $\mathrm{Al}$ & $\begin{array}{c}150 M \\
250\end{array}$ & $\begin{array}{c}200 M \\
300\end{array}$ & $\begin{array}{c}250 M \\
350\end{array}$ & $300 \mathrm{M}$ \\
\hline & $\mathrm{ZnAl15}$ & $120 \mathrm{M}$ & $150 M$ & 200M & $250 M$ \\
\hline & AlMg5 & $\begin{array}{c}200 M \\
250\end{array}$ & $\begin{array}{c}250 M \\
300\end{array}$ & $\begin{array}{c}300 \mathrm{M} \\
350\end{array}$ & \\
\hline $\begin{array}{c}\text { Woda } \\
\text { gorąca do } \\
100^{\circ} \mathrm{C}\end{array}$ & $\begin{array}{c}\mathrm{Al} \\
\mathrm{AlMg} 5\end{array}$ & $\begin{array}{l}250 \\
250\end{array}$ & $\begin{array}{l}300 \\
300\end{array}$ & & \\
\hline
\end{tabular}

\section{Natryskiwanie powłok}

Przebieg procesu natryskiwania cieplnego w zależności od zastosowanej odmiany może być stosunkowo prosty lub znacznie bardziej skomplikowany, niemniej jednak w każdym przypadku sprowadza się do stopienia i rozpylenia lub znacznego nagrzania materiału powłokowego, przyspieszenia go w strumieniu natryskowym i skierowania na powierzchnię modyfikowanego przedmiotu. W kolejnym etapie dochodzi do uderzenia 
rozpędzonych cząstek materiału powłokowego w warstwę wierzchnią modyfikowanego materiału i połączenia z nim. Charakterystyczną cechą natryskiwania jest brak nadtopienia podłoża. Stosunkowo wysoka energia cieplna i kinetyczna cząstek w strumieniu natryskowym umożliwia uzyskanie przyczepności powłoki do podłoża. Połączenie powłoki z warstwą wierzchnią podłoża ma charakter złożony i częściowo polega na mechanicznym zakleszczeniu cząstek powłoki w nierównościach podłoża, w części na adhezyjnym (wiązania międzycząsteczkowe) oddziaływaniu materiału podłoża i powłoki, a niekiedy może mieć lokalnie charakter wiązań atomowych lub być efektem powstania dyfuzyjnej warstwy przejściowej. Natryskiwanie termiczne umożliwia wykonywanie powłok różnych metali i stopów, które mogą pełnić funkcję ochronną, dekoracyjną lub regeneracyjną [5, 6, 11].

$\mathrm{Na}$ potrzeby badań zastosowano natryskiwanie łukowe, w którym źródłem ciepła jest łuk elektryczny jarzący się swobodnie pomiędzy dwoma drutami stanowiącymi materiał powłokowy. Do prawidłowej realizacji procesu niezbędna jest precyzyjna synchronizacja prowadzenia drutów względem siebie (posuwu) oraz prędkości ich topienia (mocy łuku elektrycznego). Topiony materiał drutów jest rozpylany i przyspieszany

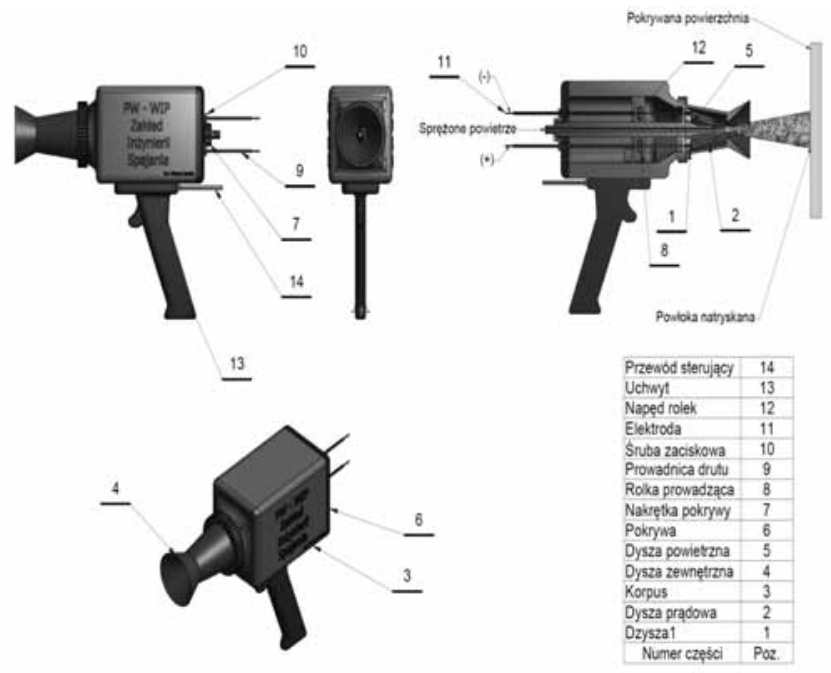

Rys. 1. Schemat pistoletu do natryskiwania łukowego [8] Fig. 1. The scheme of arc spraying gun [8]

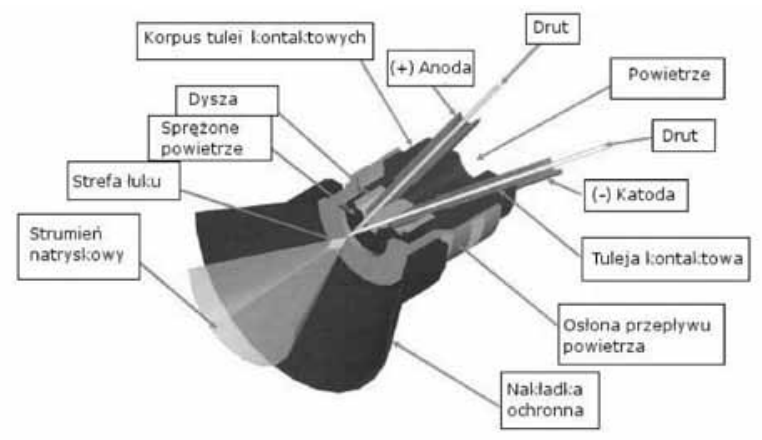

Rys. 2. Schemat obszaru topienia drutu w pistolecie do natryskiwania łukowego [4]

Fig. 2. The scheme of the melting area of a wire in arc spraying gun [4] strumieniem powietrza, tworząc strumień natryskowy. Na rysunku 1 przedstawiono schemat pistoletu do natryskiwania łukowego, a na rysunku 2 pokazano jego szczegółową budowę w obszarze topienia drutu.

W ramach badań wykonano serię prób natryskiwania łukowego agregatem Metallisation S350 ochronnych powłok anodowych Al i Zn. Celem badań było porównanie podstawowych właściwości powłok.

Metale natryskiwano na specjalnie spreparowane próbki stalowe o grubości $3 \mathrm{~mm}$ w kształcie prostokąta $(20 \times 30 \mathrm{~mm})$ i koła (ø25 mm). Powierzchnię do natryskiwania przygotowywano na poziomie Sa 2,5 przez śrutowanie pneumatyczne w komorze Blastlux SciTeeX śrutem stalowym kruszonym. Przebieg procesu natryskiwania opisano dalej. Do natryskiwania powłoki cynkowej zastosowano drut firmy Metallisation cynkowy o średnicy $2,3 \mathrm{~mm}$, a do natryskiwania powłoki aluminiowej drut aluminiowy firmy Metallisation o średnicy $1,6 \mathrm{~mm}$. W tablicy II zestawiono parametry natryskiwania cynku i aluminium. Natryskiwanie cynku i aluminium odbywało się w porównywalnych warunkach. Parametry natryskiwania dla obu materiałów były zbliżone. Różna średnica drutu, tj. 2,3 mm dla cynku i 1,6 mm dla aluminium, determinowała różną wartość posuwu drutu - 1,3 $\mathrm{m} / \mathrm{min}$ podczas natryskiwania cynku i $8,5 \mathrm{~m} / \mathrm{min}$ podczas natryskiwania aluminium.

Tablica II. Parametry natryskiwania powłok $\mathrm{Zn}$ i Al

Table II. The parameters of arc spraying of $\mathrm{Zn}$ and $\mathrm{Al}$ coatings

\begin{tabular}{|l|c|c|}
\hline \multicolumn{1}{|c|}{ Grubość powłoki } & Powłoka Zn & Powłoka Al \\
\hline Grubość powłoki, $\mu \mathrm{m}$ & $200 / 900 / 1100$ & $340 / 620 / 780$ \\
\hline Napięcie łuku, V & 24 & 24 \\
\hline Natężenie prądu, A & 220 & 230 \\
\hline Ciśnienie powietrza, bar & 4,5 & 4,5 \\
\hline Posuw drutu, m/min & 1,3 & 8,5 \\
\hline Średnica drutu, mm & 2,3 & 1,6 \\
\hline $\begin{array}{l}\text { Temperatura podłoża, }{ }^{\circ} \mathrm{C} \\
\text { Temperatura powłoki po } \\
\text { natryskiwaniu }\end{array}$ & 45 & 45 \\
\hline
\end{tabular}

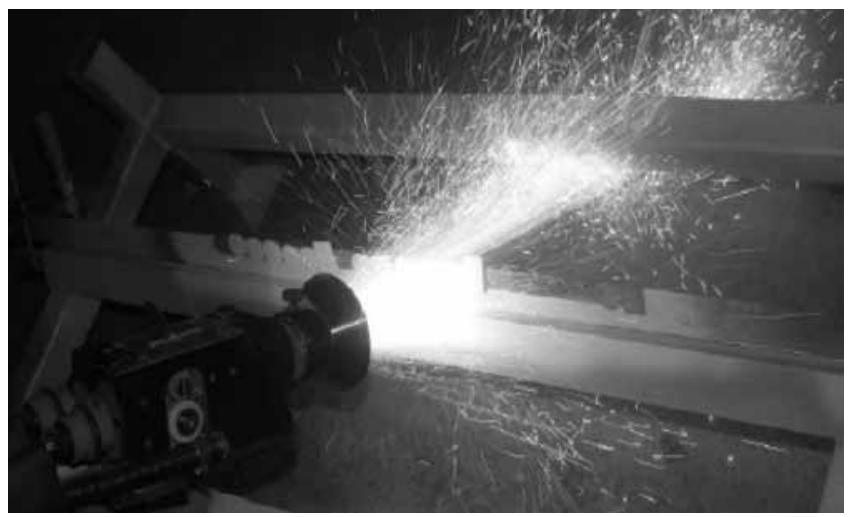

Rys. 3. Natryskiwanie łukowe

Fig. 3. Arc spraying process 


\section{Badania metalograficzne}

Preparatyka zgładów metalograficznych zawierała pobranie próbek, inkludowanie w żywicy epoksydowej, szlifowanie na papierach ściernych o ziarnistości: $100,250,360,500,800,1200$ oraz polerowanie wodna zawiesiną $\mathrm{Al}_{2} \mathrm{O}_{3}$ o uziarnieniu $1 \mu \mathrm{m}$. Badania metalograficzne zostały wykonane na mikroskopie świetlnym Olympus ze zintegrowanym aparatem cyfrowym, wykorzystującym technikę obserwacji w polu jasnym.

Na rysunkach 4 i 5 przedstawiono mikrostruktury powłok aluminium o różnej grubości natryskiwanych łukowo na podłoże stalowe S235JR. Powłoki te charakteryzują się niską porowatością, równomierną grubością na całej obserwowanej powierzchni, dobrze przylegają do podłoża stalowego oraz są ciągłe.

Na rysunkach 6 i 7 zostały przedstawione mikrostruktury powłok cynkowych natryskiwanych łukowo na podłoże stalowe S235JR różniące się grubością. Zaprezentowane powłoki również charakteryzują się równomierną grubością na całej obserwowanej powierzchni, dobrze przylegają do podłoża stalowego oraz są ciągłe. Natomiast, w przeciwieństwie do powłok aluminiowych, w granicy międzyfazowej powłoka-podłoże występuje strefa pośrednia charakteryzująca się występowaniem nowej fazy.

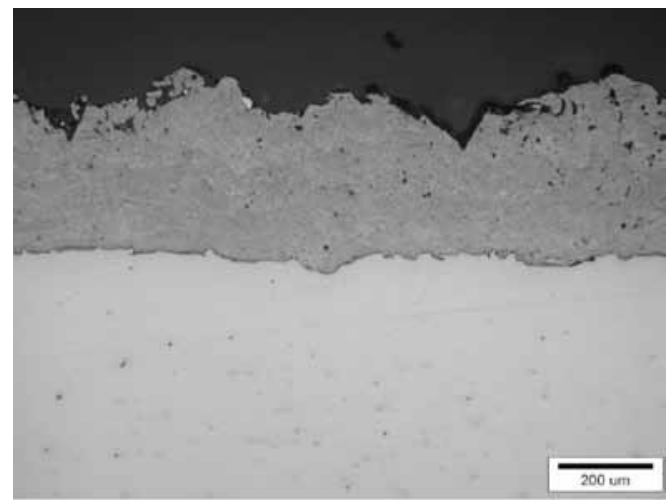

Rys. 4. Mikrostruktura powłoki Al o grubości ok. 0,34 mm natryskiwanej łukowo na podłoże stalowe S235JR, bez trawienia

Fig. 4. The microstructure of Al coating with a thickness of approximately $0.34 \mathrm{~mm}$, deposited by arc spraying onto S235JR steel substrate, without etching

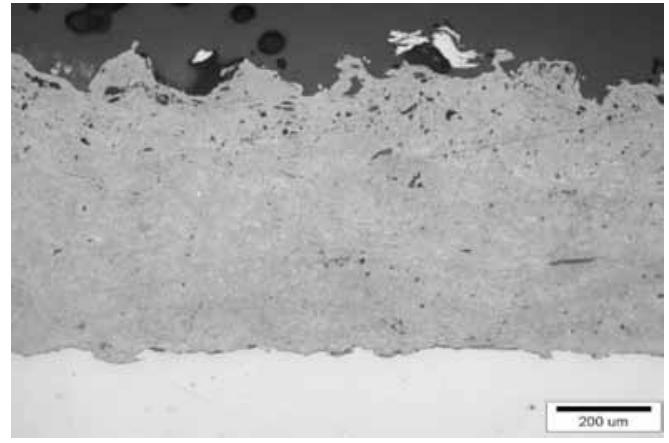

Rys. 5. Mikrostruktura powłoki Al o grubości ok. 0,78 mm natryskiwanej łukowo na podłoże stalowe S235JR, bez trawienia

Fig. 5. The microstructure of Al coating with a thickness of approximately $0.78 \mathrm{~mm}$, deposited by arc spraying onto S235JR steel substrate, without etching

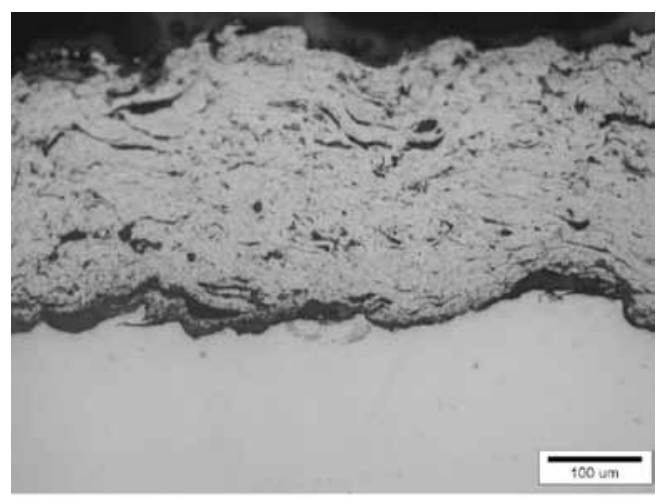

Rys. 6. Mikrostruktura powłoki Zn o grubości ok. 0,2 mm natryskiwanej łukowo na podłoże stalowe S235JR, bez trawienia

Fig. 6. The microstructure of $\mathrm{Zn}$ coating with a thickness of approximately $0.2 \mathrm{~mm}$, deposited by arc spraying onto S235JR steel substrate, without etching

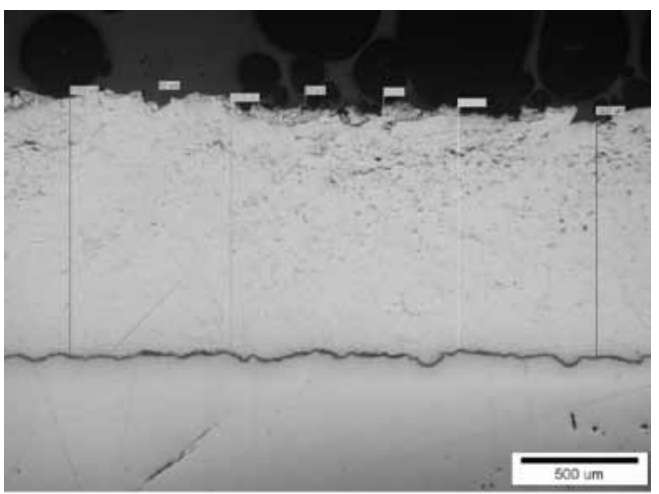

Rys. 7. Mikrostruktura powłoki Zn o grubości ok. 1,1 mm natryskiwanej łukowo na podłoże stalowe S235JR, bez trawienia

Fig. 7. The microstructure of $\mathrm{Zn}$ coating with a thickness of approximately $1.1 \mathrm{~mm}$, deposited by arc spraying onto S235JR steel substrate, without etching

\section{Pomiary twardości}

Do pomiarów twardości zastosowano mikrotwardościomierz Leitz Wetzlar. Rozkłady twardości zostały wykonane w skali $\mu \mathrm{HV} 0,05$ w płaszczyźnie prostopadłej do powierzchni w kierunku podłoże-powłoka. Na rysunku 8 pokazano wykres ilustrujący rozkłady twardości w porównywanych powłokach.

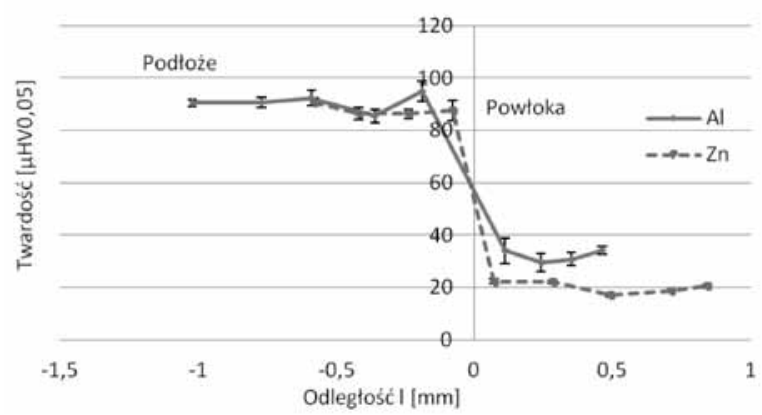

Rys. 8. Rozkłady twardości w podłożu i natryskiwanych powłokach Al oraz $\mathrm{Zn}$

Fig. 8. The hardness distribution in the steel substrate and in the deposited Al and $\mathrm{Zn}$ coatings 
Twardość powłoki aluminiowej wynosi ok. 30 $\mu \mathrm{HV} 0,05$ i jest o ok. 10 jednostek wyższa niż twardość powłoki cynkowej. W obu przypadkach twardość stalowego podłoża nie uległa zmianie na skutek działania cyklu cieplnego natryskiwania i wynosi ok. $90 \mu \mathrm{HV} 0,05$. Średnia twardość powłok nie zmienia się w funkcji odległości od granicy podłoże-powłoka, a zarejestrowane odchylenie standardowe od wartości średniej zawiera się w zakresie kilku jednostek. Wynik ten świadczy o stosunkowo wysokiej jednorodności powłok w całej ich objętości.

\section{Badania naprężeń własnych}

Do określenia naprężeń w nałożonych powłokach wykorzystano pomiar ugięcia próbek po procesie natryskiwania. W celu pomiaru ugięcia próbek zaprojektowano specjalny przyrząd pokazany na rysunku 9, bazujący na precyzyjnym cyfrowym czujniku zegarowym sprzęgniętym z gniazdem składającym się z sześciu elementów jednoznacznie ustalających próbkę przez odebranie wszystkich sześciu stopni swobody. Przed natryskiwaniem kalibrowano czujnik na nieodkształconej próbce, a po nałożeniu powłoki i ostygnięciu próbki mierzono jej ugięcie powstające $w$ efekcie indukowania się w złączu sił skurczowych i momentów gnących powstających na skutek różnych właściwości fizycznych powłoki i podłoża oraz nierównomiernego rozkładu temperatury.

Na podstawie zmierzonego ugięcia $h$ płyt próbnych i odległości między podporami $a=27 \mathrm{~mm}$ obliczono promień krzywizny $r$ natryskiwanej próbki.

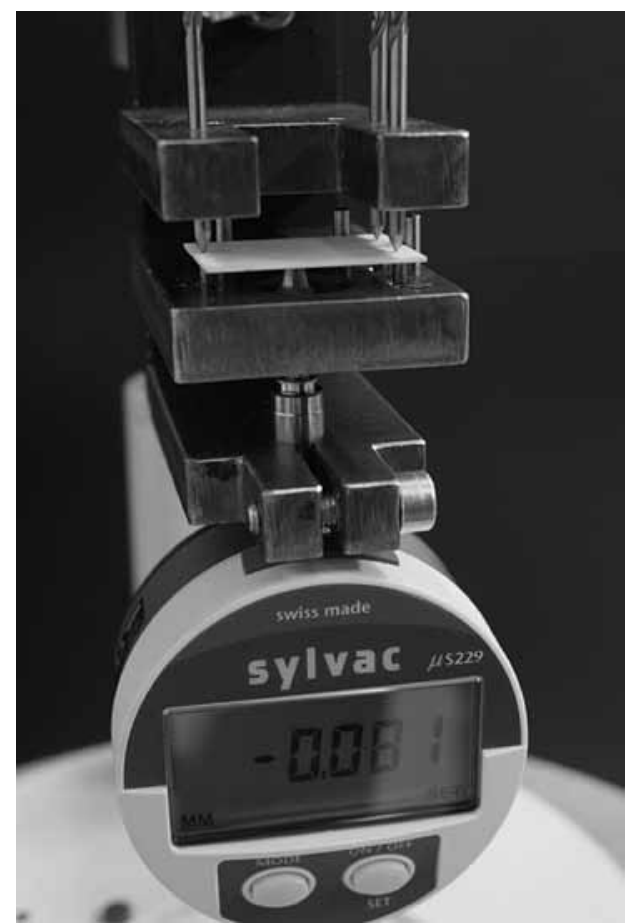

Rys. 9. Przyrząd do pomiaru ugięcia natryskiwanych próbek Fig. 9. The digital gauge used for deflection measurement of the sprayed samples
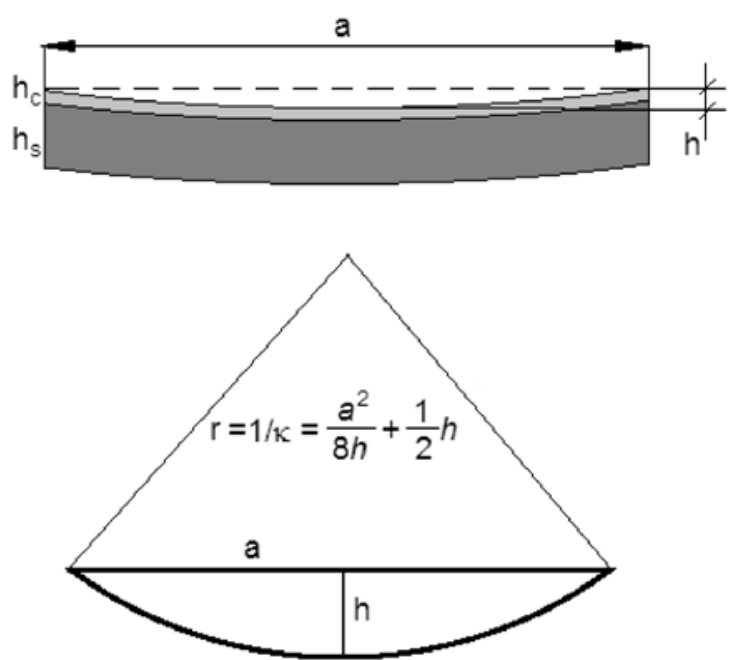

Rys. 10. Geometria odkształconej próbki zastosowana do wyznaczenia promienia krzywizny

Fig. 10. The geometry of the deformed samples that was used to determine the radius of sample curvature

Na podstawie równań Stoneya [9] i teorii ugięcia związanej z wyznaczaniem naprężeń przez pomiar krzywizny ugięcia, średnie naprężenie własne w powłoce $(\sigma)$ można obliczyć z zależności:

$$
\sigma=\frac{1}{6} \frac{E_{s}}{\left(1-v_{s}\right)} \frac{h_{s}^{2}}{h_{c}}\left(\frac{1}{r_{2}}-\frac{1}{r_{1}}\right)
$$

gdzie:

$E_{s}$ - moduł Younga materiału podłoża,

$v_{\mathrm{s}}$ - liczba Poissona,

$h_{c}$ - grubość powłoki,

$h_{s}$ - grubość podłoża.

W równaniu tym $r_{1}$ i $r_{2}$ są promieniami krzywizny podłoża przed nałożeniem powłoki $\left(r_{1}\right)$ i po nałożeniu powłoki $\left(r_{2}\right)$. Ze względu na każdorazowe zerowanie czujnika dla podłoża stalowego S235JR człon $\left(1 / r_{1}\right)$ został pominięty. W związku z tym średnie naprężenie własne w powłoce można określić wyrażeniem:

$$
\sigma=\frac{1}{6} \frac{E_{s}}{\left(1-v_{s}\right)} \frac{h_{s}^{2}}{h_{c}} \frac{1}{r_{2}}
$$

W tablicach III i IV zamieszczono wyniki pomiarów grubości i wygięcia próbek, oraz obliczone na podstawie równania Stoneya wartości naprężeń własnych w powłokach $\mathrm{Zn}$ i Al.

Tablica III. Wyniki pomiarów grubości, ugięcia próbki oraz obliczonych naprężeń własnych w powłokach Zn na podłożu S235JR Table III. The results of the thickness measurements, the deflection of the sample and calculated residual stresses in the $\mathrm{Zn}$ coatings deposited on S235JR substrate

\begin{tabular}{|c|c|c|c|c|}
\hline $\begin{array}{c}\mathrm{Nr} \\
\text { próbki } \\
\mathrm{Zn}\end{array}$ & $\begin{array}{c}\text { Grubość } \\
\text { powłoki } \\
\mu \mathrm{m}\end{array}$ & $\begin{array}{c}\text { Grubość } \\
\text { podłoża } \mathrm{h}_{\mathrm{s}} \\
\mu \mathrm{m}\end{array}$ & $\begin{array}{c}\text { Ugięcie h } \\
\mu \mathrm{m}\end{array}$ & $\begin{array}{c}\text { Naprężenie } \\
\sigma, \mathrm{MPa}\end{array}$ \\
\hline 1 & 226 & 3000 & 52 & 1065 \\
\hline 2 & 885 & 3000 & 74 & 387 \\
\hline 3 & 1100 & 3000 & 105 & 442 \\
\hline
\end{tabular}


Tablica IV. Wyniki pomiarów grubości, ugięcia próbki oraz obliczonych napreżeń własnych w powłokach Al na podłożu S235JR

Table IV. The results of the thickness measurements, the deflection of the sample and calculated residual stresses in the Al coatings deposited on S235JR substrate

\begin{tabular}{|c|c|c|c|c|}
\hline $\begin{array}{c}\mathrm{Nr} \\
\text { próbki } \\
\mathrm{Al}\end{array}$ & $\begin{array}{c}\text { Grubość } \\
\text { powłoki } \\
\mu \mathrm{m}\end{array}$ & $\begin{array}{c}\text { Grubość } \\
\text { podłoża } \mathrm{h}_{\mathrm{s}} \\
\mu \mathrm{m}\end{array}$ & $\begin{array}{c}\text { Ugięcie } \mathrm{h} \\
\mu \mathrm{m}\end{array}$ & $\begin{array}{c}\text { Naprężenie } \\
\sigma, \mathrm{MPa}\end{array}$ \\
\hline 1 & 336 & 3000 & 11 & 122 \\
\hline 2 & 616 & 3000 & 14 & 105 \\
\hline 3 & 784 & 3000 & 18 & 106 \\
\hline
\end{tabular}

Na rysunkach 11 i 12 zostały przedstawione wykresy zmierzonego ugięcia próbki w funkcji grubości powłoki Zn i Al oraz naprężenia własne $\sigma$ w powłokach $Z n$ i Al obliczone na podstawie krzywizny wygięcia próbek po procesie natryskiwania w funkcji grubości powłoki.

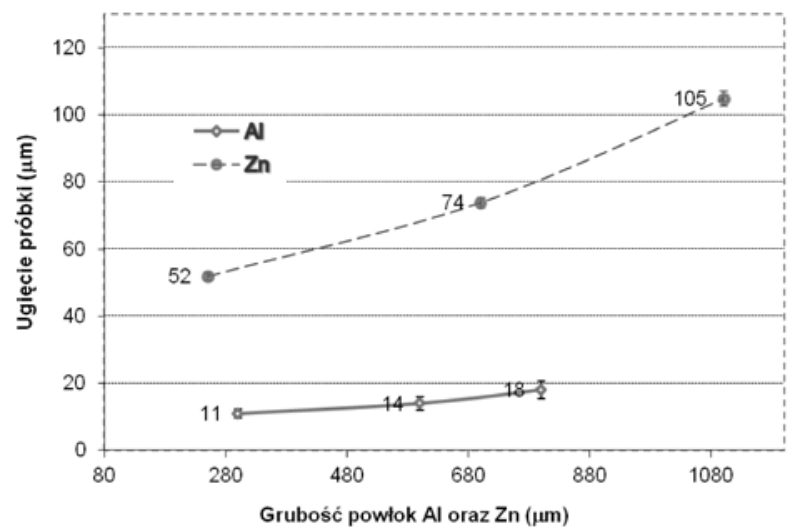

Rys. 11. Wykres ugięcia próbek natryskiwanych Al i Zn na podłożu S235JR w funkcji grubości uzyskanych powłok

Fig. 11. The deflection of the sample as a function of the thickness of Al and Zn coatings sprayed onto the substrate of S235JR steel

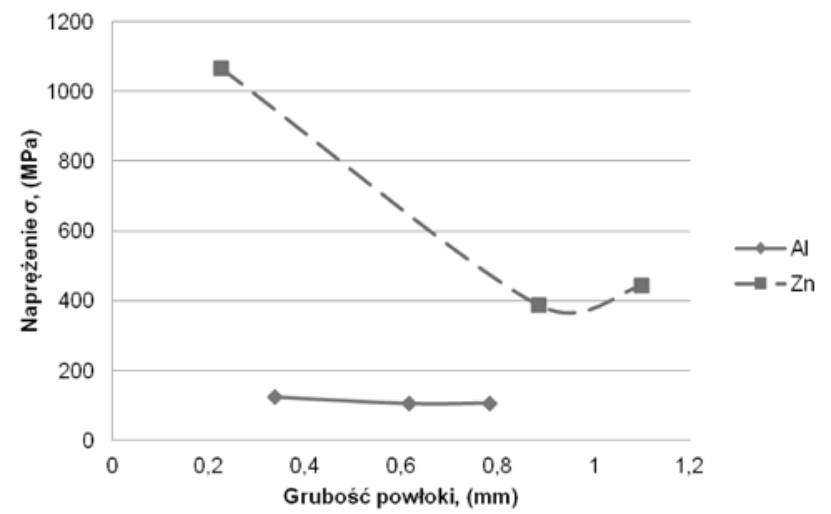

Rys. 12. Średnie naprężenie własne $\sigma$ w powłokach Zn oraz Al obliczone na podstawie krzywizny wygięcia próbek po procesie natryskiwania w funkcji grubości powłoki

Fig. 12. The mean residual stress $\sigma$ in $\mathrm{Zn}$ and Al coatings calculated based on the sample curvature measured after spraying as a function of the coating thickness

\section{Pomiar przyczepności}

Badania przyczepności wykonano na podstawie PN-EN 582 dla układu powłoka Al oraz Zn na podłożu stalowym S235JR. Przyczepność określona została metoda odrywania $R_{H}$ (wytrzymałość określona w statycznej próbie rozciągania, która wynika z ilorazu najwyższej siły $F_{m}$ i przekroju próbki na powierzchni przełomu). W doświadczeniu zastosowano próbkę typu B składającą się z dwóch przeciwpróbek oraz z wklejonej pomiędzy nie próbki w kształcie dysku jednostronnie pokrytego powłoką natryskiwaną Zn oraz Al (rys. 13). Dyski zostały przyklejone do przeciwpróbek klejem termoutwardzalnym 3M-2214 Regular, zgodnie z zaleceniami producenta. Próbki sklejano w specjalnym przyrządzie pryzmowym, który zapewniał współosiowość przeciwpróbek.

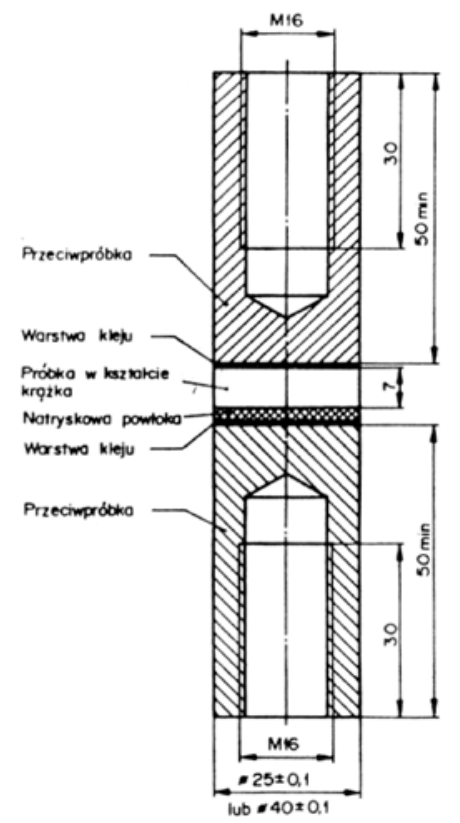

Rys. 13. Schemat przygotowania próbek do testu przyczepności

Fig. 13. The scheme of samples preparation for the adhesion test

Przyczepność powłok natryskiwanych zależy od wielu czynników technologicznych i właściwości materiałów powłoki i podłoża [7]. Podczas badania przyczepności w obu przypadkach powłok cynkowych i aluminiowych rejestrowano utratę spójności w połączeniu powłoka-podłoże. Lokalizacja przebiegu pękania w połączeniu świadczy o tym, iż jest to najsłabszy element złącza. Badania przyczepności wykonywano w obu przypadkach dla trzech różnych grubości powłok, po cztery próby dla każdej wartości grubości (tabl. V).

Tablica V. Wyniki prób statycznego rozciągania podczas badania przyczepności powłok Al oraz Zn do podłoża S235JR

Table V. The results of the static tensile tests of $\mathrm{Al}$ and $\mathrm{Zn}$ coatings adhesion to the substrate

\begin{tabular}{|c|c|c|c|}
\hline \multirow{2}{*}{ Powłoka } & $\begin{array}{c}\text { Grubość } \\
\text { powłoki } \\
\mu \mathrm{m}\end{array}$ & $\begin{array}{c}\text { Średnia } \\
\text { arytmetyczna } \\
\text { przyczepności } \\
\text { MPa }\end{array}$ & $\begin{array}{c}\text { Odchylenie } \\
\text { standardowe }\end{array}$ \\
\hline \multirow{3}{*}{$\mathrm{Zn}$} & 226 & 5,35 & 1,25 \\
\cline { 2 - 4 } & 885 & 4,98 & 0,63 \\
\cline { 2 - 4 } & 1100 & 4,65 & 1,03 \\
\hline \multirow{3}{*}{$\mathrm{Al}$} & 336 & 7,60 & 1,35 \\
\cline { 2 - 4 } & 616 & 7,30 & 1,34 \\
\cline { 2 - 4 } & 784 & 7,08 & 0,98 \\
\hline
\end{tabular}




\section{Wnioski}

Metoda natryskiwania łukowego powłok anodowych na stali znajduje zastosowanie w zabezpieczaniu konstrukcji stalowych przed działaniem korozji. Wykorzystywana jest zarówno na etapie wytwarzania konstrukcji, montażu, jak i podczas napraw. Powłoki cynkowe i aluminiowe natryskiwane łukowo na podłoże stalowe S235JR charakteryzują się wystarczającą przyczepnością do podłoża w kontekście roli jaką pełnią, to jest protektora $w$ ogniwie galwanicznym. W warunkach technologicznego wytwarzania powłok ochronnych nie zaleca się przekraczania grubości $0,35 \mathrm{~mm}$.

Na podstawie wykonanych badań sformułowano następujące wnioski:

- Warstwa wierzchnia powłok cynkowych natryskiwanych łukowo charakteryzuje się blisko dwukrotnie mniejszą chropowatością niż powłok aluminiowych.

- Uzyskane połączenia podłoża z powłoką zarówno cynkową, jak i aluminiową są dobrej jakości, tzn. materiał powłok dobrze wypełnia wszystkie nierówności podłoża stalowego i połączenie jest ciągłe.

- Powłoki aluminiowe mają większą przyczepność do podłoża o ok. $40 \%$ niż powłokicynkowe maja większą przyczepność do podłoża o ok. $40 \%$.
- Dla obu powłok wraz ze wzrostem ich grubości maleje przyczepność do podłoża.

- Średnie naprężenia własne $\sigma \mathrm{w}$ powłoce aluminiowej w zakresie grubości od ok. 0,3 do $0,8 \mathrm{~mm}$ zmieniają się nieznacznie.

- Średnie naprężenia własne $\sigma \mathrm{w}$ powłoce cynkowej w zakresie grubości od ok. 0,25 do $1,1 \mathrm{~mm}$ są bardzo wysokie przy małej grubości powłoki, obniżając się szybko wraz ze wzrostem grubości do ok. $0,8 \mathrm{~mm}$.

- Z wykresów na rysunkach 11 i 12 wynika, że średni poziom naprężeń własnych w powłokach $w$ nieznacznym stopniu zależy od grubości powłoki. Jedynie dla powłoki cynkowej przy bardzo małej grubości redystrybucja naprężeń własnych w wyniku odkształcenia plastycznego metalu powłoki nie jest w stanie zrekompensować dużej różnicy współczynników rozszerzalności cieplnej cynku i stalowego podłoża, która w głównej mierze ma wpływ na siły skurczowe w złączu.

- Twardość powłoki aluminiowej wynosi ok. $30 \mu \mathrm{HV} 0,05$ i jest o ok. 10 jednostek wyższa niż twardość powłoki cynkowej.

\section{Literatura}

[1] Baszkiewicz J., Kamiński M.: Korozja materiałów, Oficyna Wydawnicza Politechniki Warszawskiej 2006.

[2] Blicharski M.: Inżynieria powierzchni, WNT, Warszawa 2009.

[3] Burakowski T., Wierzchoń T.: Inżynieria powierzchni metali, WNT, Warszawa 1995.

[4] Borowy M.: Natryskiwanie łukowe powłok anodowych, Praca magisterska, Politechnika Warszawska, Wydział Inżynierii Produkcji, 2013.

[5] Brennek J., Milewski W.: Natryskiwanie cieplne powłok ochronnych, Instytut Wydawniczy CRZZ, Warszawa 1978.

[6] Chmielewski T., Golański D.: Właściwości powłok tytanowych natryskiwanych termicznie na podłoża ceramiczne AIN

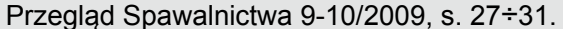

[7] Milewski W.: Wpływ współczynnika wnikania ciepła na powierzchniach styku na przyczepność powłok natryskiwanych cieplnie, Wydawnictwo Czasopism i Książek Technicznych, Warszawa 2006.

[8] Rosiak M.: Natryskiwanie termiczne powłok intermetalicznych (Ni-Al) na podłoża stalowe, Praca magisterska, Politechnika Warszawska, Wydział Inżynierii Produkcji, 2013.

[9] Stoney G.G.: The tension of metallic films deposited by electrolysis, Proceedings of the Royal Society (London) A82, s. $172 \div 175$.

[10] Tkaczyk S. (pod redakcją): Powłoki Ochronne, Wydawnictwo Politechniki Śląskiej, Gliwice 1994.

[11]Zimmerman J.: Golański D., Chmielewski T., Włosiński W., Model obliczeniowy do analizy naprężeń własnych w układzie powłoka-podłoże podczas nanoszenia powłok metodami termicznymi, Przegląd Spawalnictwa 1/2013, s. $12 \div 17$.

\section{Miesięczne i roczne spisy treści oraz streszczenia artykułów opublikowanych w Przeglądzie Spawalnictwa są dostępne na stronie internetowej:}

WWW.pspaw.ps.pl 